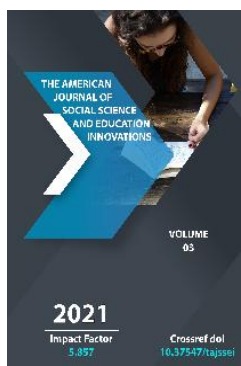

\title{
Shaping Students' Spiritual Worldviews Through Fine Arts
}

Sultanov Hayitboy Eraliyevich

Associate Professor, Department Of "Fine Arts", Chirchik State Pedagogical Institute, Uzbekistan

Journal Website:

http://theamericanjour

nals.com/index.php/taj

ssei

Copyright: Original content from this work may be used under the terms of the creative commons attributes 4.0 licence.

\section{ABSTRACT}

The article explains the problems of the current era of globalization, the importance of developing creative qualities in students through the fine arts within the innovative cluster of pedagogical education, the formation of a spiritual worldview in the "teacher-student" system. At the same time, it deals with the issues of cultivating the spiritual worldview of students, which is an integral component of ensuring continuity and continuity in education.

\section{KEYWORDS}

Students, innovative technology, educational cluster, spiritual education, teacher-student, fine arts, creativity, circle.

\section{INTRODUCTION}

As a result of the rapid penetration of innovative technologies in all spheres, the rapid acceleration of the exchange of information, it has become common in our time for many young people to be exposed to cultures that run counter to national 
traditions. A new worldview, a generational shift prone to unconventional thinking, and their aspirations are increasingly changing. At the same time, the changing spirituality of the younger generation, the problems of developing artistic thinking and the requirements for the formation of creative abilities, the emergence of new modern artistic methods of depiction in the educational process also poses great challenges to art education. The lack of formation of spiritual worldview in some students, setting high goals, self-knowledge, mobilization for growth, insufficient development of will, perseverance, diligence, mobility also have a negative impact on the quality of education. The current state of society is characterized by a disproportion that leads to misunderstanding and misunderstanding of these aesthetic values. The spectator, accustomed to living in virtual relationships, increasingly moving away from nature, can not better understand the value of national theatrical art, museums of fine and applied arts, galleries, the heritage of our ancestors, national values in our lives. In addition, there are insufficient teaching materials that provide methodological support for teachers in the field of spiritual education, including methodological manuals in the field of spiritual education, the necessary textbooks for students [1].

It is unfortunate that the young generation, brought up in such an environment, in many respects does not understand the classics of our national culture and is indifferent to our values. In fact, the role of science, education, culture and art in the modern conditions of scientific and technological progress, which we are fascinated by, is growing [2]. In young people who have learned to get all the information from the internet, the interest in shows, sensations, to get the attention of others on the internet in any way is very strong. It has become commonplace to try to become famous by filming accidents and scandals and posting them on the Internet. In young people, emotional empathy, a sincere attitude to the essence, is disappearing.

Even in the bosom of beautiful nature, they search for beauty on internet sites.

Indifferent to the environment, feeling a natural beauty, they do not feel that the features of enjoying it are disappearing. Reading educational materials only on the phone, performing tasks only on the phone, communicating with nature, with people only on the phone, extinguishes their feelings about the whole reality. Because it is clear that the information received from the phone, the pleasure received from nature, does not give the feeling received in the process of reading the book.

As a result of such global changes, the need for art in solving the problems of spiritual education of young people is growing. The importance of fine arts in the cultural development of mankind has increased.

The purpose of the study. Such rapid development of modern technologies and the current state of the education system require its revision and reform in line with modern requirements. This article examines the importance of PTIK cooperation in filling the spiritual gaps in the entire system of continuing education, ways to engage students in the visual arts through nontraditional methods and thus achieve clear positive results in their spiritual education. 
The need for a new approach to working with students in secondary and vocational schools, as well as in higher education in the field of fine arts, the need to introduce new technologies in education will be studied. Such methods should meet modern requirements, be interesting, high quality, actively develop the knowledge and creative potential of schoolchildren, identify talented children, help them to form and reveal their talents in all areas. We must not forget that the first impressions that children receive about the environment in the course of fine arts lessons gradually lead to artistic thinking about the changes taking place in nature and society, and an emotional approach to reality. The teacher must have high pedagogical skills in order not to extinguish such feelings that inspire children. The educator must organize the learning process through the principle of systematization and step-by-step, directing students to creativity. To do this, the educator must constantly strive to improve their professional skills and performance.

\section{LITERATURE REVIEW}

Many of our scientists have worked on this topic. R. Ishmukhamedov's research analyzes the modern requirements to the educational process, its content, the peculiarities of the organization of the educational process and educational work in groups of students, the theoretical and practical foundations of educational technology, methods of special training and educational technologies [3].

In her monograph, K.U. Najmiddinova [4] tries to find solutions to the problems of family upbringing. The interrelationship and integrity of socio-economic development and spiritual and moral education in Sh.Sh. Olimov's research work, its role in the system of harmoniously developed generation, historical roots, the development of spiritual and moral education in the ancient East, the content, goals and objectives of spiritual and moral education in professional colleges, scientific and pedagogical bases and ways of its improvement are shown [5]. In their research, the B.B. Baymetov, X.E. Sultanovs tried to solve problems in the spiritual upbringing of students and young people through the fine arts. B. Khusanov [6] has studied the importance and necessity of the cluster of aesthetic education in ensuring the continuity and continuity of the general education system with education.

\section{MATERIALS AND METHODS}

The scientific essence of this article is determined by the fact that in the context of the development of high technology, the vast majority of young people are connected to mobile phones and the Internet, finding solutions to the problems of educating a harmoniously developed generation in education has become an urgent task around the world. Nowadays, the use of the power of art in the formation of the spiritual upbringing of young people is more effective and plays an important role in developing in them a sense of beauty, enjoyment, appreciation. The article provides a scientifically substantiated opportunity for a fine arts teacher to organize this process. The object of research. The object of research was to increase the effectiveness of spiritual and educational work in secondary schools through the establishment of cluster cooperation, to achieve the effectiveness of the spiritual development of students. The research used the method of teamwork on the principle of 
teacher-student, student-student in the system "Ustoz-shogird" [Teacher-student] through the innovative educational cluster, methods of directing to independent research.

Higher education institutions, which play the role of integrators of vocational education and science regional culture, play a special role in the innovative development of the regions. In this new landscape, universities, local governments or other educational institutions must make wise use of opportunities such as mediating, assisting and supporting cluster partnerships [7-10]. The correct use of technologies and methodological opportunities of the educational cluster formed in higher education is a factor in achieving high efficiency in increasing the effectiveness of spiritual and educational work with students in the system of continuing education. We know that teaching methodology is based on scientific knowledge of pedagogy, psychology, aesthetics and art history. A science-based methodology requires a teacher to take an active, emotionally enthusiastic, and creative approach to pedagogical activities. Methodology, as an art of teaching, puts the teacher the right approach in communicating with students, anticipating what he or she wants, meeting his or her needs, and helping him or them promptly. The teaching materials that the teacher gives them should also be simple and clear. In addition, the task of the teacher is to be able to convey complex concepts to students simply and easily[11-17].

The current programs of our education system make more use of the classical methods of the process of teaching creativity in the fine arts.
However, in the current process of globalization with the development of information technology, many non-traditional ways to develop creativity and strengthen creative thinking are coming from abroad. This is due to the emergence of interest in various events and national traditions of early childhood, the manifestation of his good qualities in the circle of peers, family, the desire to succeed in everything, independent evaluation of peers' behaviour and actions, the emergence of spiritual and moral attitude to others. begins. In fact, today's young people love innovation, they are interested in working in different ways.

It would be expedient to solve the abovementioned problems on the basis of their propensity for mobile devices. At the same time, it is expedient not to give up new ICT tools for young people, but to increase their interest in creativity through these tools, thereby enriching their spiritual world, cultivating artistic thinking, spirituality. Diversity in creativity is a guarantee of success and certainly contributes to the development of the creative activity. To achieve the quality of education, the main task of modern education should be to avoid exactly the same in creativity, to support any methods that direct creativity. Along with the development of creativity, cultivating their spiritual outlook is an integral component of ensuring continuity and continuity in the educational process. This can be seen in the experience of Chirchik State Pedagogical Institute of Tashkent region based on the educational cluster in the field of "Fine Arts and Engineering Graphics" aimed at both creative and spiritual education of students and young people. 
In various circles organized at the department, by directing students and young people to creativity and profession, sufficient conditions are created for the development of their spiritual worldview. In these circles, a chain of organic actions has been formed, from the school teacher to the student and the faculty of the institute. In addition to directing students to creativity, the teacher provides an opportunity for them to educate their students both creatively and spiritually.

Students will be able to see how quickly senior students can find information on their creative activities on the Internet, based on their own experience, the rules of step-by-step work. The student, together with his more experienced brothers and sisters, performs a series of artistic decorations and exhibitions to create, to feel the difficulties in it, to prepare his creative work for the exhibition. The creative process, which began with the discussion of a simple sketch with the participation of experienced teachers, skilled painters, masters of applied decorative arts, will continue until the presentation of completed paintings, works of art by talented students and teachers. In doing so, the creative student learns not only the secrets of creativity, but also ways to analyze their own work and the works of others, to observe the strengths and weaknesses, and to think creatively. This creative environment, based on an educational cluster with the participation of a university representative, a student-teacher and a schoolboy, also ensures the continuity of the "Teacher-Apprentice" system. The creative process, based on the principle of "heard-seen-performed", creates favourable conditions for its participants to be educated both creatively and spiritually. Such classes serve as a process of combining theory and practice aimed at developing the student's readiness for professional and pedagogical activities [18].

In such a creative environment, the activities of talented students and pupils, professors and teachers of the institute, the rapid attention and spiritual stimulation of skilled artists increase the interest of students in the visual arts. Such a new, systematic approach to education guarantees the development of students' ability to describe, as well as the formation of basic qualities in the spirituality of young people, the ability to express ideas in practice, free and critical thinking, independent search and analysis of information. Exhibitions and competitions organized with their creative work develop the skills of young people to correctly accept the successes and failures and draw the right conclusions [19].

\section{RESULTS}

Advances in fine and applied decorative arts enhance children's self-confidence. He resolutely overcomes his own shyness barriers to a new type of activity [20]. Creative classes not only develop children's aesthetic taste, but also acquaint them with the works of applied decorative arts and national folk crafts, provide them with the necessary creative knowledge, develop artistic work skills, and at the same time direct them to professions [18-25].

Increases the effectiveness of spiritual and educational work. Mentoring model on issues such as prevention of students from various information attacks, exposure to foreign ideas, formation of spiritual and enlightenment worldview of students with 
vocational schools, vocational guidance and preparation for independent life in the framework of the concept of "schoolspirituality and enlightenment centre" The development of cooperation on the basis of [26-31] increases efficiency. Nurturing the spiritual outlook of students is an integral component of ensuring continuity and continuity in education. Diversity in creativity is a guarantee of success and certainly contributes to the development of the creative activity. Therefore, it can be concluded that the development of creative qualities in students through the fine arts within the innovative cluster of pedagogical education, the formation of a spiritual worldview is very important in the current era of globalization.

\section{CONCLUSION}

Lack of ready-made knowledge for students leads them to independent research, active creativity. Along with the formation of creative skills, the tasks of vocational guidance of education and preparation for independent living are also carried out. Wellmannered, morally virtuous, high-spirited, knowledge-hungry, spiritually strong, broadminded young people serve as the basis for the development of any society. We believe that such young people will make a worthy contribution to the development of all aspects of socio-economic life.

\section{RECOMMENDATIONS}

Based on the findings of the study, the following practical suggestions can be made:

- Attracting the attention of the scientific community to the formation of the spiritual worldview of students in the system "Teacher-Apprentice" through an innovative educational cluster;

- Increase the efficiency and scope of research work on the topic;

- Development of recommendations for the correct use of specific features of the field of education in the field of fine arts in the formation of the spiritual worldview of students in the framework of the innovative cluster of pedagogical education, methodological support of teachers in the field of spiritual education.

\section{REFERENCES}

1. Resolution of the Cabinet of Ministers No. 1059 of December 31, 2019 "On approval of the concept of continuous spiritual education and measures for its implementation."

2. Alekseeva, S.O. (2010). Problems of teaching fine arts in a comprehensive school. Bulletin of the Adyghe State University. Series 2: Philology and art history, (2).

3. Ishmuhamedov R., Abduqodirov A., Pardaev A. (2010). Innovative technologies in education (practical recommendations for educators and group leaders of educational institutions). Tashkent. Talent. P.141.

4. Najmidinova Karimaxon Usmonovna. (2016). The role of national and universal moral culture in family education, (Monograph), Tashkent. "Justice." P.224.

5. Olimov Sh.Sh. (2015). Fundamentals of spiritual and moral education. (Monograph). -T $\quad .:$ "Science and technology", P.228. 
6. Xusanov B. (2020). Educational bases of aesthetic upbringing cluster. Science and Education, 1(1). pp. 561566.

7. Sultanov, H. Je., \& Pak, V. Sh. (2016). Ispol'zovanie novyh informacionnyh kommunikativnyh tehnologij na urokah izobrazitel'nogo iskusstva [The use of new information communication technologies in fine arts lessons]. Molodoj uchenyj, (4), 831-833. (in Russian).

8. Султанов, Х. Э. (2020). Innovation technology clusters use of technology in illustration. International Journal of Psychosocial Rehabilitatio, 24(04).

9. Sultanov, H. Je., \& Zulfiev, R. N. (2020). Perspektivy innovacionnogo klastera pedagogicheskogo obrazovanija $\mathrm{v}$ oblasti izobrazitel'nogo iskusstva [Prospects for an innovative cluster of pedagogical education in the field of fine arts.]. Science and Education, 1(9). (in Russian).

10. Sultanov, H. Je., Marasulova, I. M., Mahmudov, M. Zh., \& Bahriev, I. S. (2020). Na puti sovershenstvovanija izobrazitel'nogo iskusstva $v$ nepreryvnom obrazovanii: iz opyta raboty [Improving the Fine Arts in Continuing Education: From Work Experience]. Academic research in educational sciences, (4). (in Russian).

11. Eralievich, S. K. (2020). The importance of a cluster in achieving efficiency of educational quality. European Journal of Research and Reflection in Educational Sciences Vol, 8(11).

12. Baymetov, B. B., \& Muratov, K. K. (2020). Technologies of using the laws of constructive construction in teaching students to describe the shape of the head in the process of independent learning. Academicia: An International Multidisciplinary Research Journal, 10(12), 1416-1423. http://dx.doi.org/10.5958/2249-

7137.2020.01937.0

13. Sarvar, S., Boltabaevich, B. B., Eralievich, S. H., \& Kholmuratovich, $M$. K. (2018). Scientific and theoretical aspects of the formation of compositional abilities among students in painting classes. Magazine Modern Scientific Thought, 1(1).

14. Khalilov, R. (2021). The creative technologies for teaching students to work in short-term colors. Academicia: an international multidisciplinary research journal, 11(2), 606-610. http://dx.doi.org/10.5958/2249-

7137.2021.00448.1

15. Расулов, M. (2021). Научить студентов во внешкольных учереждениях составлять композиции на уроках резьбы по дереву. Збірник наукових праць $\Lambda$ 'ОГОг.

https://doi.org/10.36074/logos-

09.04.2021.v2.44

16. Akhmedov, M.-U., \& Kholmatova , F. (2021). Formation of creative processes in students through teaching composition in fine arts.

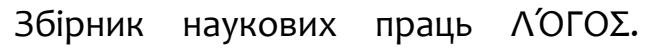
https://doi.org/10.36074//logos-

09.04.2021.v2.03

17. Djumaevich, K. K., Ergashevich, P. A., Ismailovich, A. A., Juraevich, M. M., \& Mirziyoev, S. H. M. (2020). The book of principle of human specialist. Academicia: An International Multidisciplinary Research Journal, 
10(7), $637-648$ http://dx.doi.org/10.5958/2249-

7137.2020.00837.X

18. Zikirov, M. C., Qosimova, S. F., \& Qosimov, L. M. (2021). Direction of modern design activities. Asian Journal of Multidimensional Research (AJMR), 10(2), 11-18.

19. Sultanov X.E. (2016). The role of exhibitions and competitions in preparing students for professional activities. Scientific-theoretical and methodical journal of pedagogy. T.: №1, P.116.

20. Eralievich, S. X., \& Sultanovna, M. I. M. (2020). Formation of students 'spiritual education through creative circles in secondary schools. TRANS Asian Journal of Marketing \& Management Research (TAJMMR), 9(6), 53-58.

21. Khodjamkulov Umid Negmatovich. (2020). Scientific and theoretical fundamentals of innovative cluster of pedagogical education /13.00.01 Theory of pedagogy. Dissertation for the degree of Doctor of Pedagogical Sciences (Chirchik -2020: p. History of pedagogical teachings). P.95;

22. Decree of the President of the Republic of Uzbekistan dated October 8, 2019 No PF-5847 "On approval of the Concept of development of the higher education system of the Republic of Uzbekistan until 2030".

23. Eralievich, S. K., Mukhamatsultonovna, M. I., Saidazimovich, B. I., \& Turgunovich, A. R. (2020). The Need for Creation of a Cluster of Pedagogical Innovations in the System of Continuous Education. International
Journal of Psychosocial Rehabilitation, 24(05), 6586-6591.

24. Mukhamedov GI, Khojamkulov U.N. (2019). Innovative cluster of pedagogical education: definition, description, classification (scientific brochure). T. "National University of Uzbekistan". pp.27-36.

25. Sultanov, H. Je., Hudajberdiev, P. U., \& Sobirov, S. T. (2017). Nepreryvnoe obrazovanie $v$ Uzbekistane kak trebovanie vremeni [Continuing education in Uzbekistan as a requirement of the times.]. Molodoj uchenyj, (4), 385-389. (in Russian).

26. Jabbarov, R. R. (2019). Ispol'zovanie pedagogicheskogo potenciala narodnyh hudozhestvennyh promyslov kak sredstva razvitija tvorcheskih sposobnostej uchashhihsja [Using the pedagogical potential of folk arts and crafts as a means of developing students' creative abilities]. In International Scientific Practical Conference" Improvement of the state and nonstate preschool education sectors: new forms and education content". pp-144-146. (in Russian).

27. Jabbarov, R. R. (2016). O'zlikni anglashning psihologik asoslari [Psychological basis of selfawareness]. The organization of innovative activities of the teachers: Problems and solutions. pp-444-445. (in Uzbek).

28. Bulatov, S., \& Jabbarov, R. (2016). № 2 National traditional basis of symbol of Khumo. Central Asian Journal of Education, 1.

29. Xolmuratovich, M. X. Jabbarov Rustam Ravshanovich. (2020). Amaliy va badiiy 
bezak san'ati. UO'K 76 (075); KBK 85.15; M88 ISBN 978-9943-6383-4-1. yil.

30. Jabbarov, R. (2021, March). Priorities for the development of painting. In Конференции.

31. Baymetov, B. B., \& Muratov, X. X. (2020). Methods Of Teaching Students To Do Sketches In Independent Learning. The American Journal of Social Science and Education Innovations, 2(12), 8-13. 